\title{
SACRUM PALEOPATHOLOGY IN HUNTER-GATHERERS FROM SOUTHERN PATAGONIA
}

\author{
PALEOPATOLOGÍA DEL SACRO EN CAZADORES RECOLECTORES DE \\ PATAGONIA AUSTRAL
}

\author{
Manuel Domingo D'Angelo del Campo ${ }^{1,2,3}$, Laura Medialdea ${ }^{1}$, Pamela García Laborde ${ }^{2,3}$, \\ Mónica Salemme ${ }^{4,5}$, Fernando Santiago ${ }^{4,5}$, Manuel Campo Martín ${ }^{1}$, \\ Armando González, Martín ${ }^{1}$, and Ricardo Anibal Guichón ${ }^{2,3,5}$
}

\begin{abstract}
The Sacrum is important for body stability, attachment of the lower limbs and the protection of pelvic organs. This bone may be affected by congenital, degenerative or multifactorial pathologies. The aim of the present study is to analyze sacral lesions in a well-preserved sample of remains of Southern Patagonian hunter-gatherers and the possible influences of temporal-spatial and lifestyle variables, with special attention given to the effects of Native-European contact. Pathological signs from 56 adult sacral bones from both sexes and comprising a broad chronological range (5200 years BP- $20^{\text {th }}$ century), were analyzed following the methodology proposed by Campo $(2003,2015)$. Pathologies analyzed showed that native individuals who lived in missionary areas presented a higher prevalence of lesions than samples from the remains of individuals, pre-contact and post-contact, from outside the missions, except for Schmörl nodes. The effects of age and sex showed similar patterns with respect to other populations. A high prevalence of spondylolysis was observed, similarly to Inuit samples. Since the methodology for classifying Spina Bifida Oculta -SBO- still lacks standardization, in this work, we propose using the same methods employed by Kumar and Tubbs (2011).

Key words: Environment, interethnic contact, lifestyle, spina bifida occulta, Tierra del Fuego.
\end{abstract}

El sacro es importante para la estabilidad corporal, la fijación de las extremidades inferiores y la protección de los órganos pélvicos. Este hueso puede verse afectado por patologías de índole congénito, degenerativo o multifactorial. El objetivo del presente estudio es analizar lesiones sacrales en una muestra bien preservada de cazadores-recolectores de Patagonia Austral y la posible influencia de los factores temporo-espaciales y el estilo de vida, con especial atención al momento de contacto nativo-europeo. Se analizaron 56 sacros adultos de ambos sexos fechados en un amplio rango cronológico (5.200 años AP - s. XX), siguiendo la metodología propuesta por Campo $(2003,2015)$. Las patologías analizadas mostraron que los individuos originarios que habitaron espacios misionales presentaron mayores niveles de prevalencia que sujetos pre-contacto y post-contacto fuera de la misión, excepto en el caso de los nódulos de Schmörl. Los efectos de la edad y el sexo mostraron un patrón similar al observado en otras poblaciones. Se apreció una alta prevalencia de espondilolisis, similar a la observada en Inuits. Debido a la carencia de una metodología estandarizada en la clasificación de la Espina Bífida Oculta-SBO-, este trabajo propone el uso de la propuesta por Kumar y Tubbs (2011).

Palabras claves: medio ambiente, contacto Interétnico, estilo de vida, espina bífida oculta, Tierra del Fuego.

The sacrum lies at the base of the spine, being directly related to its form, shape and stability. It is one of the three bones that composes the pelvic girdle, the structure that transfers the weight from the upper axial skeleton to the legs, provides the point of attachment for the lower limbs. It also contains and protects the organs located in the pelvic cavity
(Apazidis et al. 2011; Peleg 2007). Unlike other skeletal regions, paleopathological analysis of the spine often shows a high frequency of lesions (Campo 2003). The pathologies examined in the present study of the spine's sacral region were: Schmörl nodes (SNs), spondyloarthrosis (SA), spina bífida occulta (SBO), and spondylolysis (SL).

1 Laboratorio de Poblaciones de Pasado (LAPP), Departamento de Biología, Facultad de Ciencias, Universidad Autónoma de Madrid (UAM), Madrid, España. manueldomingodangelo@gmail.com

2 Laboratorio de Ecología Evolutiva Humana (LEEH), Facultad de Ciencias Sociales, Universidad Nacional del Centro de la Provincia de Buenos Aires (UNCPBA), Quequén, Buenos Aires, Argentina.

3 Núcleo de Estudios Interdisciplinarios sobre Poblaciones Humanas de Patagonia Austral (NEIPHPA), Facultad de Ciencias Sociales, Universidad Nacional del Centro de la Provincia de Buenos Aires (UNCPBA). Quequén, Buenos Aires, Argentina.

4 Centro Austral de Investigaciones Científicas (CADIC), Ushuaia, Tierra del Fuego, Argentina.

5 Consejo Nacional de Investigaciones Científicas y Técnicas (CONICET), Buenos Aires, Argentina.

Recibido: agosto 2019. Aceptado: abril 2020. 


\section{Sacrum Pathologies}

Schmörl nodes are a frequent defect of the vertebral bodies, fundamentally affecting the dorsolumbar region of the spine (Kyere et al. 2012; Schmörl and Junghanns 1959). They are the consequence of an intervertebral disk protrusion that involves the adjacent cartilaginous end plate of the vertebra (RANM, 2011). Its etiology is not well known, and different hypotheses have been proposed: (1) The torsional forces to which vertebrae are subjected in early stages of the development of individuals (Dar et al. 2010); (2) Biomechanical factors effect on the spine. As the lower thoracic region of the spine has limited mobility and thin intervertebral disks, there is a high risk of lesion by torsion stress (Burke 2012); (3) Morphology, fundamentally of lower back vertebra, could predispose the individual to biomechanical instability (Plomp et al. 2012);

(4) Genetical predisposition (Willians et al. 2007).

Spondyloarthrosis is a type of osteoarthritis to the spine frequently observed in the archaeological record (Ortner 2003; Weiss and Jurmain 2007). It is characterized by an initial degeneration of intervertebral disks that may be linked to a disk protrusion and mild osteophytic reaction. The disk height loss, together with the repeated abnormal intersomatic movements, cause a variation in the normal disposition of the apophyseal surface of the joints, resulting in their functional overload, which is often accompanied by degenerative defects (RANM 2011). The etiology of such an anomaly is considered multifactorial. As bones have a limited level of reaction, different pathologies have the same clinical manifestation and cause similar bone defects (Weiss and Jurmain 2007). The joint lesions related to SA are osteophytes, lipping, and eburnation, the latter being considered as a pathognomonic sign (Campo 2015; Rogers and Waldron 1995).

Spondylolysis is a defect of the spine, involving any vertebra, in which a fracture of the pars interarticularis separates the neural arch from the body of the vertebrae. It occurs in the fourth and fifth lumbar vertebrae in $95 \%$ of cases (Grogan et al. 1982). Clinical evidence suggests repetitive trauma as one of the most probable causes of such a defect (Duerson et al. 2016). Nevertheless, hereditary predisposition of the vertebral structure (Wynne-Davies and Scott 1979; Yamada et al. 2013) and SBO (Fredrickson et al. 1984; WynneDavies and Scott 1979) have been also suggested as influential factors for developing this pathology. To date, its etiology has been multifactorial, including causes such as a stress fracture linked to congenital weakness of the pars interarticularis in some cases (Krenz and Troup 1973; Peng 2016; Ward et al. 2010). SL is asymptomatic in most cases, but back pain may be present, particularly when displacement of the vertebrae occurs, a disorder known as spondylolisthesis (Haun and Kettner 2005), although the etiopathogenesis of both conditions are different (Merbs 1996a).

Spina bifida occulta is a congenital anomaly affecting more frequently the lumbosacral region (Barnes 1994; Ferembach 1963). It is characterized by the incomplete fusion of the neural vertebral arch, thereby creating a small cleft. When such a lesion occurs, the neural tube remains in place without displacement of the spine. It is one of the most common developmental defects in archaeological samples and the most common in the spine (Barnes 1994; Masnicova and Venus 2003; Mosothwane and Stein 2009; Sarry El-Din and El-Shafy El Banna 2006). The etiology is multifactorial and complex, resulting in a combination of genetic and environmental factors (Seller 1994). In medical practice, $\mathrm{SBO}$ is a common condition with little clinical significance. However, studies evidence that this anomaly could be associated with lower back pain, posterior disk herniation, urodynamic problems and other abnormalities of the lower urinary tract, backache, enuresis, and neurological abnormalities of the feet (Armstrong 2012; Avrahami et al. 1994; Fidas et al. 1987). SBO has a wide spectrum of prevalence depending on the population; nevertheless, the range varies between populations. For example: Hamann-Todd's collection (USA) indicates a prevalence between 1,2 to 50\% (Eubanks and Cheruvu 2009), while the documented collection at Adelaide University (Australia) reports a range of between 2 and 25\% (Albrecht et al. 2007).

Before analyzing these anomalies, it is recommended to assess the preservation and taphonomic state of the bones under examination and to consider factors related to sample quality and quantity, which may limit the conclusions (Rascón et al. 2011; Séguy and Buchet 2011; Waldron 1987).

\section{Biocultural Context}

Southern South America and the Tierra del Fuego archipelago show special biogeographical characteristics, 
conforming a set of islands and channels close to the Antarctica. On the one hand, Southern Patagonian populations are characterized by presenting a high degree of isolation from the rest of the American populations as evidenced by genetic studies (Crespo et al. 2018; de la Fuente et al. 2015, 2018; Lalueza 1997; Pérez and Monteiro 2009) and morphometric (Cocilovo and Guichón 1986; González-José et al. 2002; Guichón 1994; Pérez and Monteiro 2009; Pérez et al. 2007; Varela et al. 1993-94). On the other hand, there is an internal degree of homogeneity between such populations as reported in previous genetic (Crespo et al. 2017; García-Bour et al. 2004; Lalueza 1997) and morphometric (Bernal et al. 2010; González-Jose 2003; Hernández et al. 1997; Lalueza et al. 1996) works. From the Early Holocene to continuous contact with non-native populations, local societies were terrestrial and maritime nomadic hunter-gatherers with a high mobility (Borrero 2001; Borrero and Martin 2018; Guichón 1994; Santiago 2009). The continuity of these lifestyles throughout this period has been reported in archaeological and stable isotope studies (Barberena 2002; Borrero and Barberena 2006; Valenzuela et al. 2019; Zangrando 2009).

The contact between natives and foreign people can be divided in two different periods: (1) Discontinuous contact, from the $16^{\text {th }}-19^{\text {th }}$ centuries. The territory was explored by the Europeans, but settlement attempts in the area were scarce and not successful (Martucci 2016); (2) Continuous contact, from mid- $19^{\text {th }}$ century to the present date. A contingent of foreign people arrived in this area, creating settlements and farms which occupied the places usually used by natives to live, hunt and gather. The foreigners' lifestyle was imposed upon them, involving deeper transformations in their way of life and cultural matters, as well as social changes that implied important biological repercussions (Casali 2011). These societies changed from a high mobility nomadism to a sedentary lifestyle with a high level of population density and sometimes overcrowding. They were forced to assimilate new physical labors, clothes, diet, hygiene practices, mystic world views and religion, funeral rituals, monogamous relationships, mono-familial housing and a concept that had not previously existed for the natives: private property (Casali 2011; Martucci 2016). Native-European contact also implied a variation in the health of natives, increasing their risk of developing certain diseases. Several studies have indicated an increase in the prevalence of pathological signs in post-contact samples, mainly in missional areas (D'Angelo del Campo et al. 2017; García Laborde et al. 2010; Guichón et al. 2006; Moreno Estefanell et al. 2018).

Finally, it is important to note that Southern Patagonia it is characterized by isolated inhumations with few exceptions (Guichón et al. 2001; L'Heureux and Amorosi 2009, 2010; L'Heureux and Barberena 2008; Santiago et al. 2011) and without cemeteries before the European Contact times. Nevertheless, three necropolises from the contact period are known: cemetery of the Salesian Mission "Nuestra Señora de La Candelaria" (SMLC, Río Grande, Argentina), cemetery of the Salesian Mission "San Rafael" (Dawson Island, Chile) and cemetery of the Anglican Mission (Ushuaia, Argentina); all associated with religious missions.

\section{Objective}

The aim of this study was to analyze sacral pathologies in a sample of 56 hunter-gatherers from Southern Patagonia and the possible influences of temporal-spatial and lifestyle variables ogether with an approximation of the effects of NativeEuropean contact in native populations. From what has been indicated by historical documents and previous paleopathological studies in other bones, we hypothesize that the prevalence of sacral lesion may have been higher after contact between natives and Europeans, especially in SMLC.

\section{Material and Methods}

The sample analyzed was composed of 56 sacrum bones of human skeletons from Southern Patagonian, continental and insular territories below $50^{\circ} \mathrm{S}$ (Figure 1; Table 1, Supplementary information table 1). The remains are housed in Argentinian institutions: Museo del Fin del Mundo (MFM, Ushuaia), Centro Austral de Investigaciones Científicas (CADIC, Ushuaia), Museo Fagnano de la Misión Nuestra Señora de La Candelaria (Río Grande), Puerto Santa Cruz skeletal collection (Puerto Santa Cruz), Laboratorio de Ecología Evolutiva Humana (Quequén -LEEH-) and Museo Etnográfico Juan B. Ambrosetti (ciudad de Buenos Aires), in addition to a collection housed in the Instituto de la Patagonia (IP, Punta Arenas, Chile). 


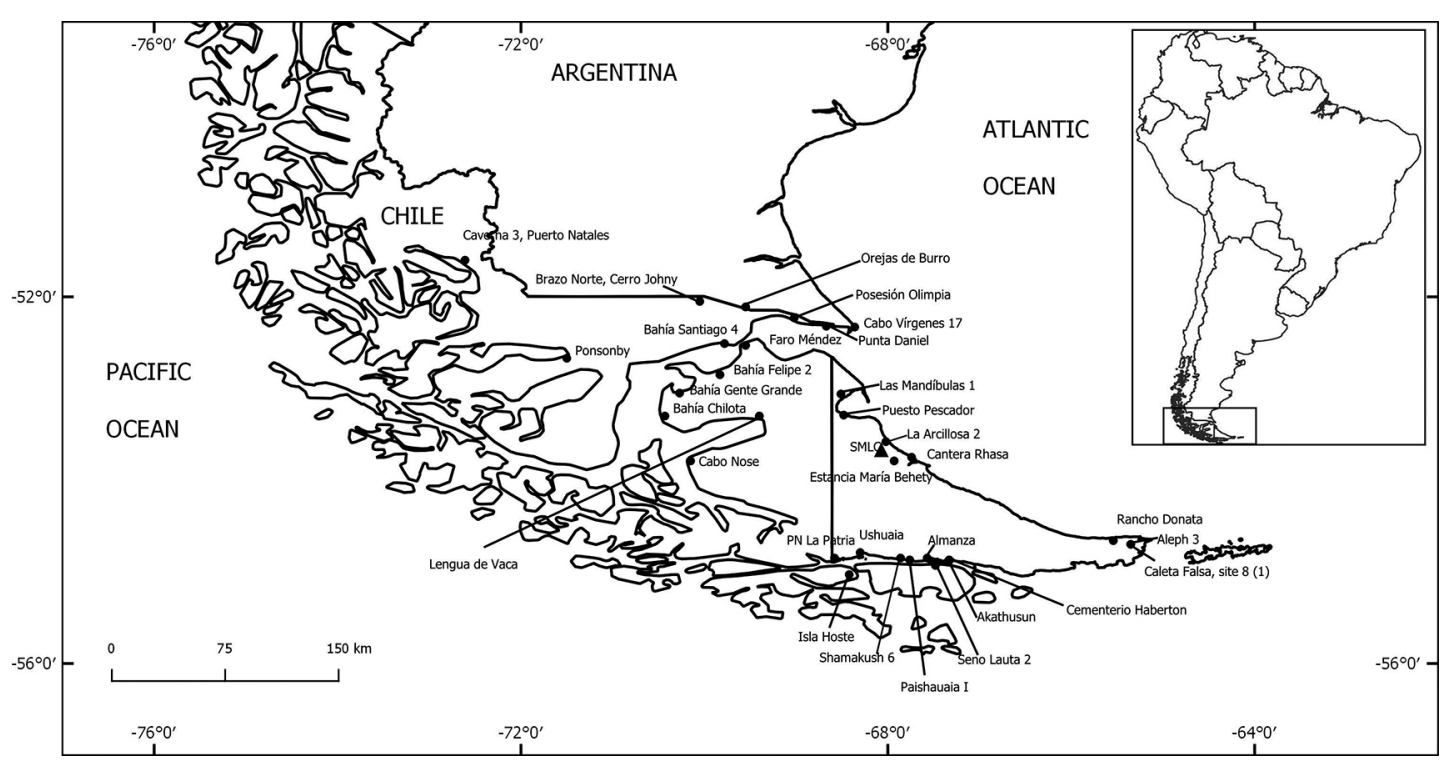

Figure 1. Location of archaeological sites analyzed in Southern Patagonia.

Localización de los sitios arqueológicos estudiados en Patagonia Austral.

Table 1. Skeletons and prevalence of pathological signs and taphonomy from Southern Patagonia, classified by chronology, period, age, and sex.

Esqueletos y prevalencia de signos patológicos y tafonomía de Patagonia Austral, clasificados por cronología, periodo, edad y sexo.

\begin{tabular}{|c|c|c|c|c|c|c|c|c|c|c|c|}
\hline & & & & Preser & vation & & & Patholog & ies, n (\%) & & \\
\hline & & & & & & & Body & & $\mathrm{AF}$ & SDP & SI \\
\hline & & & II & PQnS & PQ1S & SN & SA & Lipping & Eburnation & $\mathrm{SBO}$ & $\mathrm{SL}$ \\
\hline & & & & & & $\mathrm{n}(\%)$ & $\mathrm{n}(\%)$ & $\mathrm{n}(\%)$ & $\mathrm{n}(\%)$ & $\mathrm{n}(\%)$ & $\mathrm{n}(\%)$ \\
\hline & Pre-contact & & 15 & 93.3 & 81.84 & $2(13.3)$ & $10(66.7)$ & $4(28.6)$ & $3(21.4)$ & $2(18,2)$ & $1(6.7)$ \\
\hline & Peri-contact & & 2 & 100 & 95.9 & 0 & 0 & 0 & $1(100)$ & 0 & 0 \\
\hline Period & & $\begin{array}{l}\text { Outside } \\
\text { SMLC }\end{array}$ & 10 & 94 & 88.42 & 0 & $2(22.2)$ & $3(30)$ & $4(40)$ & $2(20)$ & 0 \\
\hline & Post-contact & SMLC & 11 & 100 & 94 & $1(11.1)$ & $3(33.3)$ & $6(54.5)$ & $6(54.5)$ & $3(27.3)$ & $1(9.1)$ \\
\hline & & Total & 21 & 97.1 & 91.4 & $1(5.3)$ & $5(27.8)$ & $9(42.8)$ & $10(47.6)$ & $5(23.8)$ & $1(4.8)$ \\
\hline & $\mathrm{C}$ & & 17 & 97.6 & 92.9 & $1(5.9)$ & $8(47.1)$ & $5(29.4)$ & $7(41.2)$ & $1(5.9)$ & 0 \\
\hline Region & IC & & 26 & 99.2 & 93 & $2(8.3)$ & $10(41.7)$ & $9(36)$ & $10(40)$ & $5(19.2)$ & $1(3.8)$ \\
\hline & $\mathrm{C}$ & & 11 & 87.3 & 78.5 & $1(10)$ & $4(40)$ & $1(10)$ & $1(10)$ & $1(9.1)$ & $1(9.1)$ \\
\hline$\Delta$ & $\leq$ & 30 & 17 & 97.6 & 89.2 & $1(5.9)$ & $6(35.3)$ & $3(17.6)$ & $6(35.3)$ & $4(23.5)$ & $2(11.8)$ \\
\hline 118C & & 30 & 24 & 98.3 & 92 & $3(12.5)$ & $11(52.4)$ & $12(57.1)$ & $12(57.1)$ & $2(8.7)$ & 0 \\
\hline & $\mathrm{F}$ & & 17 & 97.6 & 89.7 & $1(6.2)$ & $9(56.2)$ & $5(31.2)$ & $5(31.2)$ & $2(13.2)$ & 0 \\
\hline & M & & 34 & 95.9 & 89.7 & $3(9.4)$ & $13(40.6)$ & $10(30.3)$ & $13(39.4)$ & $5(17.2)$ & $2(5.9)$ \\
\hline
\end{tabular}

Of the 56 individuals analyzed, 44 had already been sexed and their age had already been estimated in previous studies (reference column, Table 1, Supplementary information table 1). In the remaining twelve, age at death was estimated by the analysis of pubic symphyses (Brooks and Suchey 1990; Todd 1921a, 1921b), epiphyseal fusion (Buikstra and Ubelaker 1994), auricular surface (Lovejoyet al., 1985) and the metamorphosis of the fourth sternal rib end (Isçan et al. 1984). Due 
to the scarce number of skeletons over 45 years of age, skeletal remains were classified in two age ranks: $\leq 30$ years ( 17 individuals) and $>30$ years (24 skeletons); the other 15 (26.8\%) are adults but with an undetermined age. Skeletons were sexed following the methods described by Buikstra and Ubelaker (1994) based on the cranium and hip bones. The sample was composed of 34 males, 17 females and 5 undetermined. Adult individuals ( $>18$ years old at death) of both sexes, with at least 50\% of the sacrum present and comprising at least three sacral vertebrae, were included in this study. These requirements reduced the sample composed of 98 individuals to $56(57.4 \%)$.

Individuals have been dated from 5200 years BP to the $20^{\text {th }}$ century by different authors (Table 1 , Supplementary information table 1). Thus, 15 skeletons from the pre-contact period (before 500 years BP), two peri-contact period (499-400 years BP, Magellan crossed its strait homonym in 1520 AP. Given the range of error associated with chronological analyses, this time interval might have coincided at some point with the Magellan expedition) and 21 from the contact period (399 years BP - the $20^{\text {th }}$ century). From these remains, 11 were exhumed from the cemetery of the SMLC (lat. $-53.72^{\circ}$, long. $-67.79^{\circ}$ ). SMLC was settled in 1893 with the aim of "civilizing" native people. The cemetery was excavated recovering the skeletal remains of 33 adult and non-adult individuals. The necropolis was used by missionaries and natives between 1897 and 1948. From 1911, it was also used by the Allochtoon Fueguian population not affiliated with any religious order, who refer to themselves as ancient settlers (Casali 2011; García Laborde 2017; Guichón et al. 2006). There was no chronological information for 18 skeletons.

The skeletal remains were recovered from 41 archaeological sites distributed throughout the Southern Patagonia. As shown in Figure 2, the area is divided into three regions: Continent (C), Great Island (IG), and Beagle Channel (CB). There were 11 individuals (19.6\%) in C, $26(46.4 \%)$ in IG and $17(30.4 \%)$ in CB Two individuals (3.6\%) remained with no information about their origin.

The sacra were analyzed following the methodology proposed by Campo (2003, 2015). This procedure examines each segment of the

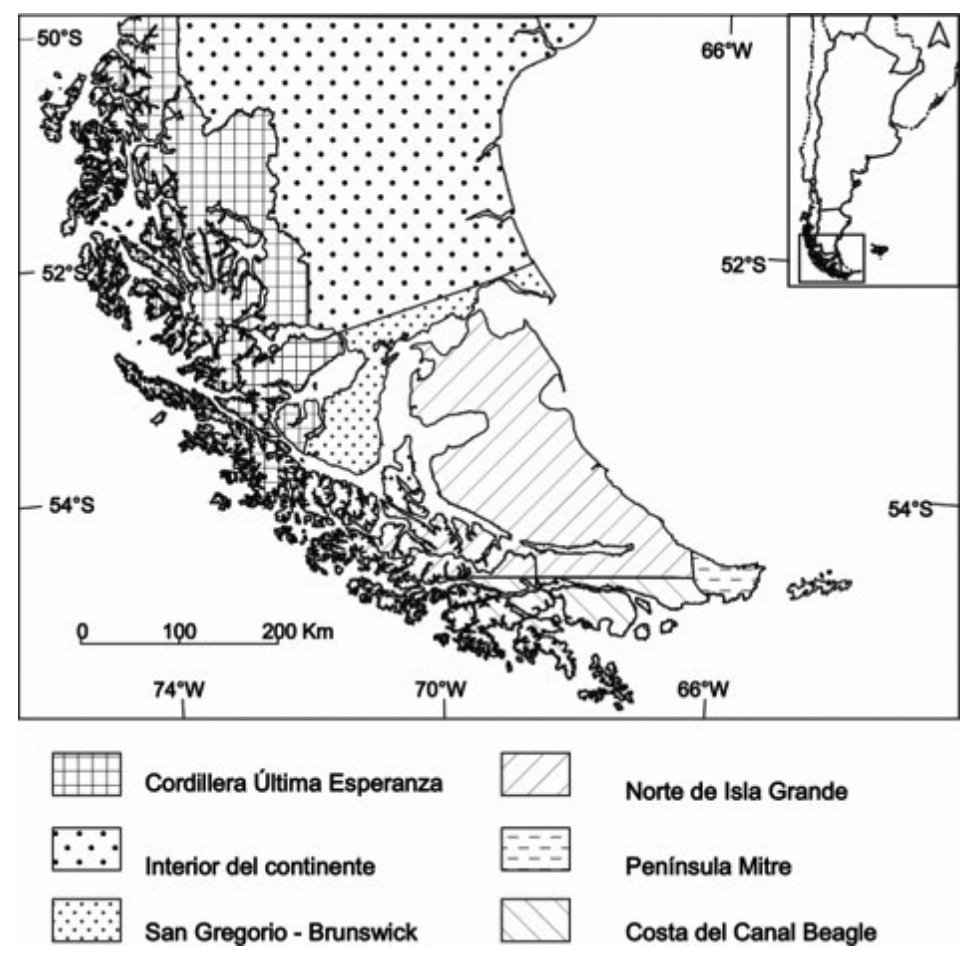

Figure 2. Geophysical areas of Southern Patagonia, modified from Borrero et al. (2001).

Áreas geofísicas de Patagonia Austral, modificado de Borrero et al. (2001). 
spine macroscopically, attending to the diverse characteristics of each region and considering several factors; with respect to the sacrum, these include preservation, SNs, SA, SL, and SBO.

Preservation was determined by means of two parameters based in the completeness of the sample:

(1) Preservation Quantitative State (PQnS), according to the formula:

$$
\mathrm{PQnS}=\frac{\text { Number of present vertebrae }}{\text { Total number of vertebrae }(5)} \times 100
$$

(2) Preservation Qualitative State (PQIS):

$$
\mathrm{PQIS}=\frac{\begin{array}{c}
\text { PQIS partial coefficient of } \\
\text { each present vertebra }
\end{array}}{\text { Theorical maximun }(7) \mathrm{x}} \times 100 .
$$

Total number of vertebrae (5)

The Partial PQIS coefficient is the result of completeness of the different structures of each vertebra (vertebral body and apophyseal joints of the vertebral arch). The theoretical maximum of partial PQIS, i.e., complete body and both arches with all the apophyseal joints, is 7 ( 3 body +2 left arch + 2 right arch). The total number of vertebrae is 5 , except for the sacrum with alterations in the number of elements (for further information on the methods, see Campo 2003, 2015). When an incomplete sacrum was found, comprising 4-7 vertebrae, the theoretical number of 5 was assumed.

Concerning pathologies in the vertebral body, two kinds of lesions were examined: (1) the presence/absence of SNs was analyzed at S1 superior's endplate. Nodes were categorized in two groups: (a) mild to moderate; (b) severe, when the negative cast of nucleus pulposus in the vertebral body presented penetration(s) or a depression of considerable depth. In such a depression cancellous bone had to be observed. Marginal ridge overcome was indicated when present. (2) Body SA, i.e., osteophytes, considering the maximum expression observed. The lateral symmetry of the endplate was examined, subdividing the vertebral body into left (L) and right $(\mathrm{R})$ sides with respect to the sagittal axis. The anomalies were classified according to (a) elevated marginal ridge with an overcome of the edge; (b) curved spikes and/or great visors; (c) ankylosis or fusion.
On the other hand, pathological conditions examined in arch elements were: (1) SA of the articular facets, i.e., defects at the two articular facets were studied independently considering: (a) Lipping, with three possible types of expression: (a.1.) sharp relief, sometimes curled with spicules; (a.2.) wide spicules formation; (a.3.) ankylosis. (b) Eburnation, two likely condition states: (b.1.) just polished; (b.2.) polished, pearl appearance, with macroporosity. (2) SLs was examined to evidence unfused fractures of the pars interaticularis located at the vertebral arch lamina. All possible defects related to this region, whether complete or incomplete, unilateral or bilateral, were recorded. (3) SBO was registered when $\mathrm{S} 1$ presented an unfused neural arch. When the aperture was produced in the other sacral vertebras (S2-S5), it was considered be hiatus sacralis as some clinical studies have pointed out (Hennenberg and Hennenberg, 1999). In order to contextualize the results of SBO from Southern Patagonia, we carried out a review of published papers on SBO in archaeological samples. Thus, SBO, SB, hiatus sacralis, dysraphism and sacrum paleopathology were used as keywords for the searching process in journals, books and $\mathrm{PhD}$ theses. Data were extracted into a database, including authors, year of publication, origin, chronology, sample size, prevalence, methodology of analysis, and lifestyle (Table 2, Supplementary information table 2).

The R package (version 3.4.4) was used for data treatment. Moreover, Microsoft Excel, R and Gimp 2 were used to generate graphical resources. For each frequency analysis, the number of affected vertebrae regarding available and observable vertebrae were considered. To explore differences by period, region, age and sex in the sacrum, we applied the ANOVA test for quantitative variables and the chi-square test for qualitative variables with a confidence level of $95 \%(\alpha=0.05)$.

\section{Results}

Both PQnS and PQ1S gave a result of over $90 \%$, showing a very good preservation of Southern Patagonia sacral bones (Table 1, Supplementary information table 1). PQnS was $100 \%$ in 48 individuals $(85.7 \%)$; $80 \%$ in $6(10.7 \%)$ and $60 \%$ in $2(3.6 \%)$. For $\mathrm{PQ} 1 \mathrm{~S}$, there was greater disparity between the sacral bones, ranging from $47.6 \%$ to $100 \%$; 33 individuals $(58.9 \%)$ presented a value of $100 \% ; 13(23.2 \%)$ were 
Table 2. Descriptive analysis of pathological signs by means of chronology, region, age and sex. Análisis descriptivo de signos patológicos por medias de cronología, región, edad y sexo.

\begin{tabular}{|c|c|c|c|c|c|c|c|}
\hline \multicolumn{8}{|c|}{ Statistical differences } \\
\hline \multicolumn{8}{|c|}{ Chronology } \\
\hline & Pre-contact & $\begin{array}{l}\text { Outside } \\
\text { SMLC }\end{array}$ & SMLC & Total & $\mathrm{DF}$ & Value & Signification \\
\hline $\mathrm{n}$ & 15 & 10 & 11 & 36 & & & \\
\hline Schmörl Nodes & 2 & 0 & 3 & 5 & 2 & 3.264 & 0.196 \\
\hline Body SA & 10 & 2 & 5 & 17 & 2 & 5.263 & 0.072 \\
\hline Lipping & 5 & 3 & 6 & 14 & 2 & 1.662 & 0.436 \\
\hline Eburnation & 4 & 4 & 6 & 14 & 2 & 2.083 & 0.353 \\
\hline \multirow[t]{3}{*}{ SBO } & 2 & 2 & 3 & 7 & 2 & 1.198 & 0.549 \\
\hline & \multicolumn{5}{|c|}{ Mean } & \multicolumn{2}{|c|}{ ANOVA } \\
\hline & Pre-contact & $\begin{array}{l}\text { Outside } \\
\text { SMLC }\end{array}$ & SMLC & Total & $\mathrm{DF}$ & F Value & Signification \\
\hline PQnS & $90.30 \pm 12.30$ & $94.00 \pm 13.50$ & $100 \pm 0.00$ & $95.57 \pm 10.8$ & 2 & 1.38 & 0.266 \\
\hline PQIS & $81.84 \pm 22.23$ & $88.42 \pm 20.01$ & $94.04 \pm 9.48$ & $87.39 \pm 18.81$ & 2 & 1.39 & 0.264 \\
\hline \multicolumn{8}{|c|}{ Region } \\
\hline & \multicolumn{4}{|c|}{ Individuals } & & \multicolumn{2}{|c|}{$\chi 2$ test } \\
\hline & $\mathrm{C}$ & IG & $\mathrm{CB}$ & Total & $\mathrm{DF}$ & Value & Signification \\
\hline $\mathrm{n}$ & 11 & 26 & 17 & 54 & & & \\
\hline Schmörl Nodes & 2 & 4 & 1 & 7 & 2 & 1.156 & 0.561 \\
\hline Body SA & 5 & 12 & 8 & 25 & 2 & 0.007 & 0.996 \\
\hline Lipping & 2 & 10 & 5 & 17 & 2 & 1.523 & 0.467 \\
\hline Eburnation & 2 & 11 & 7 & 20 & 2 & 2.112 & 0.348 \\
\hline \multirow[t]{3}{*}{ SBO } & 1 & 5 & 1 & 7 & 2 & 2.767 & 0.234 \\
\hline & \multicolumn{5}{|c|}{ Mean } & \multicolumn{2}{|c|}{ ANOVA } \\
\hline & $\mathrm{C}$ & IG & $\mathrm{CB}$ & Total & $\mathrm{DF}$ & F Value & Signification \\
\hline PQnS & $87.30 \pm 16.20$ & $99.20 \pm 3.92$ & $97.60 \pm 6.64$ & $96.47 \pm 9.55$ & 2 & 7.91 & $0.001 * *$ \\
\hline PQIS & $78.47 \pm 22.82$ & $93.02 \pm 13.37$ & $92.94 \pm 13.32$ & $90.03 \pm 16.46$ & 2 & 3.76 & $0.030^{*}$ \\
\hline \multicolumn{8}{|c|}{ Age } \\
\hline & \multicolumn{5}{|c|}{ Individuals } & \multicolumn{2}{|c|}{$\chi^{2}$ test } \\
\hline & $\leq 30$ & $>30$ & \multicolumn{2}{|c|}{ Total } & $\mathrm{DF}$ & Value & Signification \\
\hline $\mathrm{n}$ & 17 & 24 & \multicolumn{2}{|c|}{41} & & & \\
\hline Schmörl Nodes & 1 & 6 & \multicolumn{2}{|c|}{7} & 1 & 2569 & 0.109 \\
\hline Body SA & 6 & 14 & \multicolumn{2}{|c|}{20} & 1 & 2114 & 0.146 \\
\hline Lipping & 3 & 13 & \multicolumn{2}{|c|}{16} & 1 & 5577 & $0.018 *$ \\
\hline Eburnation & 6 & 13 & \multicolumn{2}{|c|}{19} & 1 & 1425 & 0.233 \\
\hline
\end{tabular}


Continuation Table 2.

\begin{tabular}{|c|c|c|c|c|c|c|}
\hline SBO & 4 & 2 & 7 & 1 & 3123 & 0.077 \\
\hline & \multicolumn{4}{|c|}{ Mean } & \multicolumn{2}{|c|}{ ANOVA } \\
\hline & $\leq 30$ & $>30$ & Total & $\mathrm{DF}$ & F Value & Signification \\
\hline PQnS & $97.60 \pm 6.64$ & $98.3 \pm 8.16$ & $98.05 \pm 7.49$ & 1 & 0.08 & 0.777 \\
\hline \multirow[t]{4}{*}{ PQ1S } & $89.15 \pm 16.92$ & $92.04 \pm 14.85$ & $90.84 \pm 15.60$ & 1 & 0.34 & 0.565 \\
\hline & & & Sex & & & \\
\hline & \multicolumn{4}{|c|}{ Individuals } & \multicolumn{2}{|c|}{$\chi^{2}$ test } \\
\hline & Female & Male & Total & $\mathrm{DF}$ & Value & Signification \\
\hline $\mathrm{n}$ & 15 & 29 & 44 & & & \\
\hline Schmörl Nodes & 2 & 5 & 7 & 1 & 0.083 & 0.774 \\
\hline Body SA & 7 & 19 & 26 & 1 & 0.981 & 0.332 \\
\hline Lipping & 6 & 11 & 17 & 1 & 0.044 & 0.834 \\
\hline Eburnation & 6 & 14 & 20 & 1 & 0.165 & 0.685 \\
\hline \multirow[t]{3}{*}{ SBO } & 2 & 5 & 7 & 1 & 0.297 & 0.586 \\
\hline & \multicolumn{3}{|c|}{ Mean } & & \multicolumn{2}{|c|}{ ANOVA } \\
\hline & Female & Male & Total & DF & F Value & Signification \\
\hline PQnS & $97.60 \pm 6.64$ & $98.3 \pm 8.16$ & $98.05 \pm 7.49$ & 1 & 0.08 & 0.777 \\
\hline PQ1S & $89.15 \pm 16.92$ & $92.04 \pm 14.85$ & $90.84 \pm 15.60$ & 1 & 0.34 & 0.565 \\
\hline
\end{tabular}

between $77.1 \%$ and $97.1 \%$; and $10(17.9 \%)$ were between $47.6 \%$ and $69 \%$. It was possible to observe chronological differences. Thus, post-contact remains exhibited higher PQnS and PQ1S than pre-contact bones; at the same time, SMLC remains showed higher values than the individuals from outside of the mission. Differences were also identified based on the region of provenience. Hence, IG had the highest level of both indexes, but its values were close to those of $\mathrm{CB}$; however, the differences in the indicators for both IG and $\mathrm{CB}$ compared to $\mathrm{C}$ was higher than $10 \%$. Age variances were also detected. For example, young adults and adults were very well-preserved with PQnS above $95 \%$ and PQIS near to or above $90 \%$. With regards to sex variations, $\mathrm{PQnS}$ was $1.7 \%$ higher in females and both cases presented values higher than 95\% (Table 1). The ANOVA test only showed significant statistical differences in the mean values for both PQIS $(p<0.05)$ and PQnS $(p<0.01)$ mean values, according to region (Table 2). A post-hoc Tukey test (Table 3) revealed that the mean value for PQIS was significantly lower in C compared to IG $(13.25, p<0.01)$ and CB $(12.42 ; p<0.05)$. PQnS was found to be significantly higher in $\mathrm{C}$ compared to IG $(11.96, p<0.01)$ and $\mathrm{CB}(10.37 p<0.01)$.

The prevalence of $\mathrm{SN}$ in $\mathrm{S} 1$ was scarce in the examined sample. Four individuals $(7.5 \%)$ showed this lesion (Table 1, Supplementary information table 1); two of them were moderate and the other two severe (Figure 3). Moreover, the individuals affected by this lesion were heterogeneously distributed by period, region, age and sex (Table 1). Pre-contact remains presented a higher prevalence $(13.3 \%)$ than post-contact (5.3\%); nevertheless, SMLC sample prevalence $(11.1 \%)$ was similar to the pre-contact

Table 3. Relationship between taphonomy indexes among regions.

Relación entre índices de tafonomía y regiones.

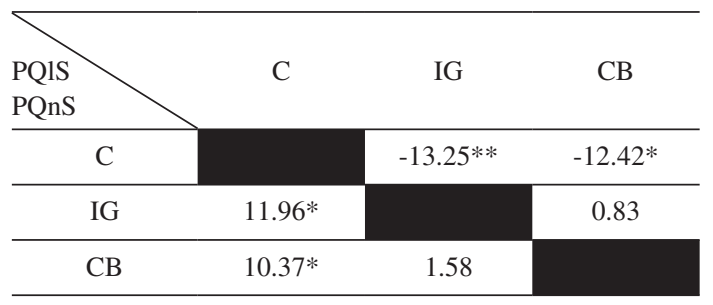


period. It should be noted that the individual (Id25884) presenting this condition was found close to the SMLC remains, but there is no chronological information available. In terms of region, there is a gradual decrease in SN prevalence along the Patagonian North-South axis. Thus, the highest prevalence was observed for C (10\%), the average in IG $(8.3 \%)$, and the smallest in CB (5.9\%). Age seemed to be an important factor for the presence of SN lesions, showing a clearly differential pattern in relation to adulthood. The prevalence was higher in males $(9.4 \%)$ than in females $(6.2 \%)$.

Another examined lesion at vertebral body level was the osteophytes existence at $\mathrm{S} 1$, which showed a prevalence of $43.4 \%$ in the examined sample (Table 1, Figure 3, Supplementary information table 1). Regarding chronology the prevalence in pre-contact $(66.7 \%)$ doubled post-contact $(27.8 \%)$, resulting in higher values $(33.3 \%)$ than outer mission individuals (22.2\%). With respect to region, South-North gradient was observed, revealing the highest values at $\mathrm{CB}$ (47.1\%) and the lowest at C (40\%). As described for SNs, the prevalence of osteophytes increased with age and female remains showed higher prevalence
(56.2\%) than male individuals $(40.6 \%)$. None of the differences were statistically significant (Table 2).

Regarding to the SA of S1 articular facets, two lesions were examined: (1) Lipping: which affects 16 individuals $(29.6 \%$-Table 1 , Supplementary information table 1), with high prevalence in postcontact sample (42.8\%), fundamentally in SMLC $(54.5 \%)$. The region with the highest prevalence was IG (36\%), followed by CB (29.4\%), and finally, with a value three times lower, by C (10\%). Similarly, to the case of osteophytes, there is an increase in the prevalence of this lesion in relation to age. The values for lipping in females $(31.2 \%)$ and males $(30.3 \%)$ were similar (Table 1). Age differences were statistically significant $(\mathrm{p}=0.018)$, the only pathological analysis that showed a significant p-value (Table 2). (2) Eburnation was observed in 19 sacra (35.2\% -Table 1, Supplementary information table 1), with the same pattern of lipping; SMLC showed the highest prevalence $(54.5 \%)$ followed by individuals from outside the mission (40\%), and finally pre-contact remains $(21.4 \%)$. However, the regional pattern varied, with $\mathrm{CB}$ showing the highest prevalence $(41.2 \%)$, followed closely by IG (40\%),
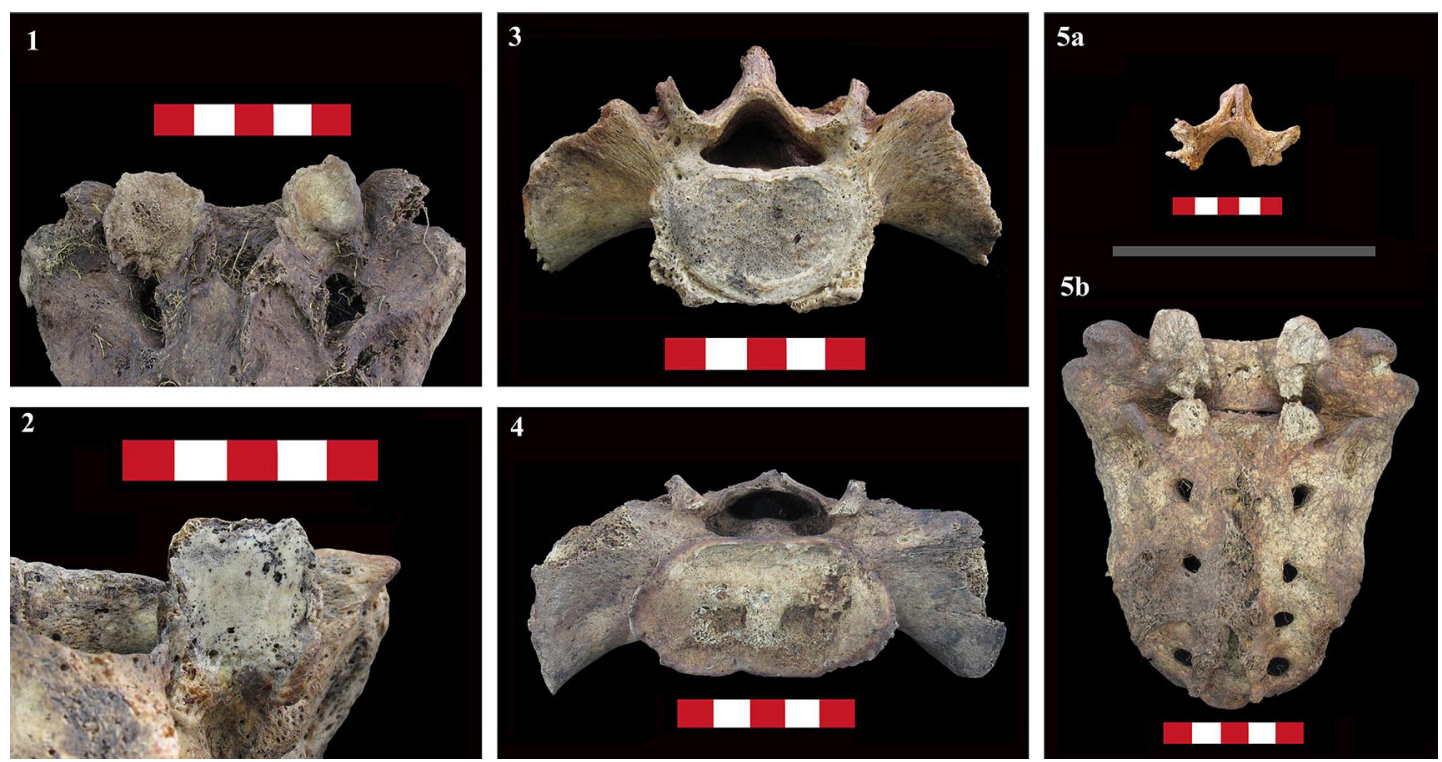

Figure 3. Pathological sacrum signs: (1) SA, lipping at left articular S1 facet with sharp relief and spicules - individual LEEH ED-10; (2) SA, eburnation at right articular S1 facet, polished with a pearl appearance and macroporous state - ind. MFM CH95; (3) SA, curved spikes on left and right sides of the S1 sacral vertebral body - ind. IP 288; (4) Severe SNs - ind. LEEH C13; (5) Complete and bilateral SPs of S1 - ind. LEEH C11: (5a) S1 arch (5b) sacral bone without S1 arch.

Signos paleopatológicos sacrales: (1) SA, labiación en la carilla articula izquierda de S1 que presenta un relieve afilado con espículas - individuo LEEH ED-10; (2) SA, eburnación en la carilla articular derecha de S1 que muestra una superficie pulida con apariencia perlosa y macroporosidad state - ind. MFM CH95; (3) SA, espículas curvadas en ambos lados, izquierdo y derecho, del cuerpo vertebral de S1 - ind. IP 288; (4) SN severo severe - ind. LEEH C13; (5) SP complete y bilateral de S1 - ind. LEEH C11: (5a) arco S1 (5b) hueso sacral sin arco en S1. 
and $\mathrm{C}$ presented a value four times lower $(10 \%)$. In the same way as other degenerative pathologies, there was an increase in of eburnation in older individuals. In this case, prevalence was higher in males (39.4\%) than in females (31.2\%), None of the differences described with respect to this pathology were statistically significant.

Two cases of SL were observed at the sacrum (3.6\%). Both consisted in a complete bilateral lesion at S1 (Figure 3). Individuals that showed the alteration were: Orejas de Burro 1 (1), a young, pre-contact man (20-25 yrs.) from SGB, and C 11 (1), a young man (20-30 yrs.) from SMLC. It should be noted that this lesion was not observed post-contact remains from outside the mission, neither in the CB region, nor in or adults (Table 1, Supplementary information table 1).

With respect to SBO, 7 individuals (12.5\%) showed unfused S1, 40 (71.4\%) exhibited hiatus sacralis, and $9(16.1 \%)$ did not present any alteration of the neural arch (Figure 4, Supplementary information table 1). Note that all individuals presenting unfused S1 also exhibited another alteration of the sacral arch. There were no cases showing the whole open vertical arch. The frequency of the anomaly varied depending on the vertebra examined: there were seven cases in S1 (12.5\%), 0 in S2, 2 in S3 (4.2\%), 13 in S4 $(27.1 \%), 35$ in S5 (72.9\%), 9 in S6 (60.0\%), and 2 in
S7 (50\%). In the same individual, the affected number of vertebras varied. Thus, $21(43.8 \%)$ presented at least one anomaly, 11 (22.9\%) two, 4 (8.3\%) three, and $3(6.3 \%)$ four. As depicted in Table 1, there were differences in SBO regarding: (1) period, where the sample from SMLC presented the highest value (27.3\%) compared to the post-contact sample from outside the mission $(20 \%)$, and the pre-contact sample (18.2\%); (2) regions, where remains from IG showed the highest prevalence (19.2\%), doubling that observed at $\mathrm{C}(9.1 \%)$, and trebling that of $\mathrm{CB}$ $(5.9 \%)$; (3) age factor, where contrary degenerative disease and $\mathrm{SN}$ patterns showed a higher prevalence in adults under 30 (23.5\%); and (4) sex, where males presented a higher prevalence $(17.2 \%)$ than females (13.2\%). However, none of these differences were statistically significant (Table 2).

Regarding the review of SBO in archaeological samples (Table 2, Supplementary information table 2), 50 works have been carried out, comprising 79 samples from different populations. 38 of these populations reported data on $\mathrm{S} 1$, although only eight considered this character to indicate an SBO diagnosis. Besides, 40 populations spread data on S1-S5. Finally, 46 works considered any sacral crest aperture as SBO. Taking continental distribution in the studied mentioned into account, African populations showed the lowest incidence values for $\mathrm{S} 1$ aperture

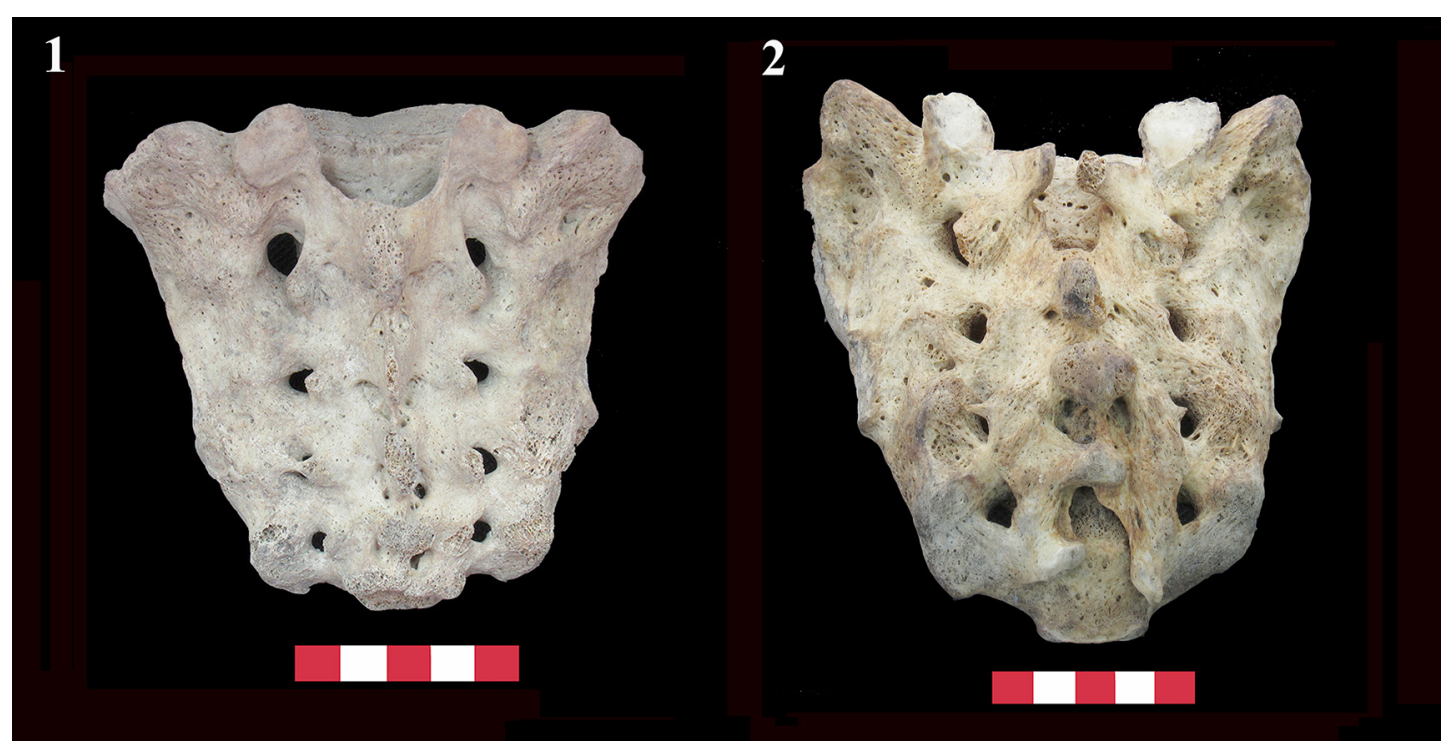

Figure 4. Variations in the sacral vertebral arch: (1) Normal sacral bone without incomplete arches - individual ME 13276; (2) Sacral bone with SBO and hiatus sacralis - ind. MFM 796 -.

Variaciones en arco vertebral sacral: (1) Sacro normal con todos los arcos cerrados - individuo ME 13276; (2) Hueso sacral con SBO y hiatus sacralis - ind. MFM 796 - 
(0.7-16.9\%), followed by European samples (0$18.4 \%)$. American populations showed intermediate values (0-12.4\%), while Asia (2.86-25\%) and Oceania $(0-32.5 \%)$ presented the highest (Table 4, Figure 5).

\section{Discussion}

Since inadequate preservation could limit and/ or reduce the possibility of identifying pathological traces, the very good preservation observed has allowed for the proper characterization, examination

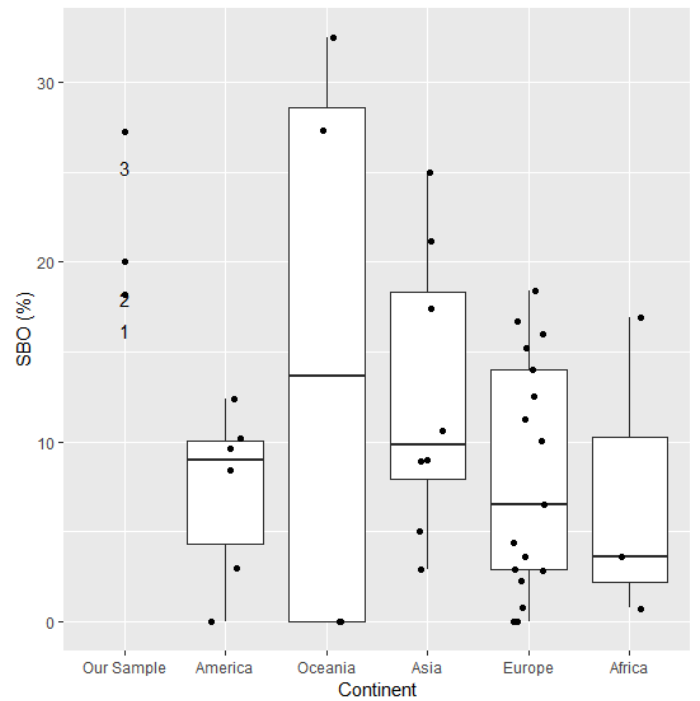

Figure 5. Jittering and box-plot, each point represents the total percentage of populations by continent. Points on the Southern Patagonia column are: (1) pre-contact, (2) contact period excluding Salessian Mission "Nuestra Señora de La Candelaria", (3) Salessian Mission "Nuestra Señora de La Candelaria".

Jittering y box-plot, cada punto representa el porcentaje total de cada población por continente. Los puntos de la columna de Patagonia Austral son: (1) pre-contacto, (2) periodo de contacto, excluyendo los individuos de la Misión Salesiana "Nuestra Señora de La Candelaria”, (3) Misión Salesiana "Nuestra Señora de La Candelaria".

Table 4. Descriptive analysis of SBO variation by continent from bibliographic review.

Análisis descriptivo de la variación de SBO por continente, revisión bibliográfica.

\begin{tabular}{lcc}
\hline \multirow{2}{*}{ Continent } & \multicolumn{2}{c}{ Spinna bifida oculta } \\
\cline { 2 - 3 } & $\mathrm{n}$ samples & prevalence $(\%)$ \\
\hline Africa & 3 & $3.6-16.9$ \\
Europe & 17 & $0-18.4$ \\
Asia & 8 & $2.86-25$ \\
Oceania & 4 & $0-32.5$ \\
America & 9 & $0-27.3$ \\
$\Sigma$ & 38 & $0-32.5$ \\
\hline
\end{tabular}

and identification of alterations in the sacral bone (Rascón et al. 2011). The scarce taphonomical alteration observed could be related to numerous factors. For example, the very good preservation observed in the SMLC sample could be related to edaphic, $\mathrm{pH}$, environmental or culturally specific characteristics of the cemetery (García Laborde et al. 2015).

The prevalence of SNs observed in the sacrum was lower than that described in the vertebral column of Southern Patagonian individuals: pre- and postcontact (Suby 2014), and SMLC (Moreno Estefanell et al. 2018). In previous studies, no references to sacrum pathologies were mentioned. The same pattern has been reported in other populations, where the prevalence of SNs in the sacrum was $0 \%$ or close to null (Burke 2012; Faccia and Williams 2008; Novak and Slaus 2011; Üstündağ 2009). The highest prevalence was found in pre-contact remains, contrary to what has been observed in the vertebral column, where SMLC presented a high prevalence of SNs, while that of pre- and post-contact samples remained approximately three times lower (Moreno Estefanell et al. 2018; Suby 2014). Some studies (Dar et al. 2010; Plomp et al. 2012; Williams et al. 2007) indicate that physical activity may not explain the presence of this lesion, as it is linked to genetic factors. In this sense, the individuals examined in this work had a great level of genetic and morphometric isolation and were ancestrally related. However, their lifestyles did differ among them due to two main causes: (1) terrestrial and maritime hunter-gatherering (2) European-Native contact. A prevalence of $75 \%$ (3/4) of SNs in the sacrum was found in human remains coming from regions traditionally associated with terrestrial hunter-gatherers. Taking into account the studies of SNs in vertebral columns individuals from southern Patagonia carried out by Moreno Estefanell et al. (2018) and Suby (2014), no evidence of human remains was reported from places traditionally associated with maritime hunter-gatherers, such as the Beagle Channel or the Cordillera Última Esperanza. Besides, half of the cases of SNs, i.e., two individuals (Id-25884 and Id-C13), come from the SMLC cemetery or nearby. Nevertheless, etiological divergences and multifactorial origins make it difficult to establish of a direct relationship between this pathology and lifestyle. As observed in the spine of individuals from pre- and post-contact from outside SMLC (Suby 2014), the higher prevalence 
was described in the $\mathrm{C}$ region. However, the differences between regions were lower in the sacrum than in the sections of the spine examined by Suby (2014), who indicated a prevalence of $62.5 \%$ in C, $12.5 \%$ in IG and $0 \%$ in CB. Regarding age, the observed pattern in the whole spine contrasted with the sample analyzed by Suby (2014), where $66 \%$ of the individuals between 20-35 years of age presented this condition. There is still no consensus effects of age on SNs. Some authors to point out a higher prevalence in mature and senile individuals (Jiménez-Brobeil et al. 2010; Novak and Slaus 2011), while others did not find differences among age groups (Dar et al. 2010; Jiménez-Brobeil et al. 2012; Üstündağ 2009). Concerning sex, the prevalence was higher in males (Burke 2012; Faccia and Williams 2008; Jiménez-Brobeil et al. 2010, 2012; Moreno Estefanell et al. 2018; Novak and Slaus2011; Suby 2014; Üstündağ 2009).

Osteophytes present in the sacrum usually show similar or lower prevalence levels with respect to the lumbar region, the last lumbar vertebrae (Jurmain and Kilgore 1995; Novak and Slaus 2011; Sofaer Derevenski 2000; Üstündağ 2009; Waldron 1991). However, some exceptions have been observed, such as the Soacha Muisca pre-contact series from what is Colombia today (Rojas-Sepúlveda et al. 2008). As in Soacha Muisca, our pre-contact Southern Patagonian remains presented higher prevalence in S1 than in L5 from pre- and post-contact and SMLC individuals. At the same time, levels at $\mathrm{S} 1$ are higher in pre-contact than in post-contact individuals, in contrast to the pattern observed in the vertebral column (Moreno Estefanell et al. 2018; Suby 2014). Nevertheless, the same analysis according to region showed a lower prevalence of Osteophytes in S1 with respect to L5 in the three areas; in contrast to the results obtained for the whole spine, where the $\mathrm{C}$ region presented the lowest prevalence (Suby 2014). As reported in other populations, age is a relevant factor and older individuals are usually more affected by spondyloarthrosis (Jiménez-Brobeil et al. 2012; Novak and Slaus 2011; Rojas-Sepúlveda et al. 2008; Van der Merwe et al. 2006; Waldron 1991; Weiss and Jurmain 2007). Furthermore, the highest prevalence observed in females in the Southern Patagonian sample is consistent with previous studies in some populations (Rojas-Sepúlveda et al. 2008), while other works reported no differences (Novak and Slaus 2011; Waldron 1991), and some of them pointed out higher values in males (Jiménez-Brobeil et al. 2012; Novak and Slaus 2011; Van der Merwe et al.
2006) as described in the vertebral column of the SMLC individuals (Moreno Estefanell et al. 2018). Thus, there has been no consensus on the effects of sex. The other two degenerative signs observed at apophyseal joints usually present a decrease in S1 (Novak and Slaus 2011; Rojas-Sepúlveda et al. 2008; Üstündağ 2009). The same pattern was observed at SMLC, where a prevalence range of $66.7 \%$ in L5 to $54.5 \%$ in S1 was reported for lipping. A similar situation was observed regarding eburnation, where the prevalence obtained for L5 was $80 \%$ and $54.5 \%$ for S1 (Moreno-Estefanell et al. 2018). As observed for osteophytes, there was an increase in the prevalence of eburnation in older individuals (Jiménez-Brobeil et al. 2012; Novak and Slaus 2011; Rojas-Sepúlveda et al. 2008; Weiss and Jurmain 2007); some authors indicate a higher prevalence in females (Rojas-Sepúlveda et al. 2008), while others in males (Jiménez-Brobeil et al. 2012; Novak and Slaus 2011). Therefore, there is no consensus about sex. However, in sacral bones from Southern Patagonia, the prevalence of lipping is higher in females and eburnation in males; these are opposite results to those observed in the vertebral column of human remains from SMLC (Moreno Estefanell et al. 2018). Traditionally, a positive relationship between degenerative disease and physical activity has been postulated (Bridges 1992; Sofaer Derevenski 2000). Nevertheless, recent studies indicate that osteoarthritis is not a good indicator of lesions deriving from physical activity; instead, they highlight subjacent genetic influence and thus, heritability, which reaches, 0.6-0.7 in the case of spinal columns (Weiss and Jurmain 2007). Furthermore, in Southern Patagonian populations, a high level of isolation and a variety of lifestyles are described. Apophyseal signs could be more related with changes in lifestyle due to the high levels of osteophyte prevalence observed in the SMLC; nevertheless, the higher prevalence of osteophytes reached in our pre-contact sample has only been reported in another pre-Columbian sample (Rojas-Sepúlveda et al. 2008). These contradictory results and multifactorial etiology, essentially the controverted relationship between activity and osteoarthritis, should be taken into consideration in further interpretations.

The presence of SL in sacrum is scarce in clinical and bioanthropological literature (Merbs 1996b). The frequency observed at Southern Patagonia (3.6\%) is similar to the results observed 
in Inuit populations from Alaska $(4,4 \%)$ and Canada $(4,1 \%)$ - Merbs 1996b -. As indicated above, the etiology of this pathology remains unclear, with congenital and lifestyle factors being the most plausible causes. Nevertheless, it is remarkable that two populations so distant from one another, such as Inuit and Southern Patagonia populations, both hunter-gatherers in cold environments with different lifestyles, presented similar levels of SL, even at the level of the spine (D'Angelo del Campo et al. 2017). This may be associated with non-congenital factors, such as those related to the environment, and not associated with lifestyle, for instance a cold climate. However, this association has not been previously studied for sacra. Hence, as observed in our Southern Patagonian sample, this lesion has been reported primarily in young males (Merbs 1996b).

SBO has been widely studied in the field of paleopathology (Kumar and Tubbs 2011). However, the comparison between different studies is difficult due to the lack of agreement on methodological features for describing and classifying lesion. For example, several authors have expressed the need for a clear classification system for the sacral canal closure (Albrecht et al. 2007; Hennenberg and Hennenberg 1999). The results obtained from the SBO review made in the present work supports this claim. Besides, SBO levels in Southern Patagonia remains within the ranges indicated for different populations (1.2-50\%). The range observed in this review was between that proposed by Albrecht et al. (2007) and Eubanks and Cheruvu (2009), but closer to the former. SBO high levels have been associated with biological isolation and endogamy (Ferembach 1963). Nevertheless, although the Southern Patagonian sample had an important degree of isolation, its SBO prevalence remains low. Only when considering the second range of prevalence $(2-25 \%)$, should SMLC individuals (27\%) be considered to have a high SBO prevalence. This value could be associated with biological isolation or a lifestyle change, as described for other pathologies reported in SMLC skeletons (Crespo et al. 2018; Lalueza 1997; D'Angelo del Campo et al. 2017; de la Fuente et al. 2015, 2018; Moreno Estefanell et al. 2018; Pérez and Monteiro 2009). The combined effect of both factors could have been an important determining factor to maintaining and even increasing the prevalence of this pathology. The frequency of SBO was higher in males as previously observed for other samples (Barnes 1994; Eubanks and Cheruvu 2009; Groza et al. 2016; Masnicová and Benus 2003; Mulhern and Wilczack 2012). Furthermore, an unexpected decrease in prevalence in relation to age was observed according to results obtained in previous studies for this pathology (Albretch et al. 2007; Eubanks and Cheruvu 2009; Groza et al. 2016; Sutow et al. 1956). As Kumar and Tubbs (2011) have indicated, the most observed hiatus sacralis pattern across different studies is a high frequency of anomalies at S4 and S5 and a slightly lower one at S3. Usually, only one or two vertebrae are affected, but this figure can be higher, particularly in the sacral neural arches (Masnicová and Venus 2003).

Finally, it is important to note some limitations of this work. First, the scarce sample size, which limited the statistical evidence of the results. As justified in the biocultural context section, the existing, available Patagonian samples are limited. Secondly, a methodological limitation was found due to the lack of a standardized method of comparing SBO results, given that almost every author who has written on this subject proposes his or her own methods. The present work proposes the generalized use of application of methods used by Kumar and Tubbs (2011) to help standardize the study of SBO, as they follow clinical descriptions of the different pathologies studied in this paper. Finally, the reason(s) underlying the SBO pattern described in the present study requires further investigation. he present study, however, offers a starting point for discussion of this topic that has not been addressed in any previous works (from the list displayed in Table 1, Supplementary information table 1).

\section{Conclusion}

Our results confirm the hypothesis that sacral pathologies in the Southern Patagonian sample show a similar pattern with respect to previous studies on pathological signs. Therefore, SMLC individuals presented a higher prevalence of such lesions than pre-contact and post-contact samples from outside SMLC, except for SNs, where pre-contact and SLMC samples showed similar values. The higher predominance observed in IG is directly related to the fact that SMLC was in this area. The effects of age and sex showed similar lesional patterns with respect to other populations. It is important 
to note that, as previously described for SL of the spine in this same population, the high prevalence of SL reported by the present study in the sacrum resembles very closely the results observed in Inuit populations.

Despite SBO being widely studied, there is still no standardized methodology for addressing this lesion, which makes it difficult to develop and discuss comparative studies. Furthermore, we strongly propose the generalized application of methods employed by Kumar and Tubbs (2011) as a standardized starting point. In the course of the present work, a continental pattern of SBO was detected, with low prevalence in Africa and Europe, intermediate in America, and high in Asia and Oceania. Future studies should involve a deeper analysis of this pattern.

Acknowledgments: We would like to express our gratitude to the Argentinian Museo del Fin del Mundo (Ushuaia), CADIC (Ushuaia), Museo Etnográfico Juan B. Ambrosetti (ciudad de Buenos Aires) and Chilean Instituto de la Patagonia (Punta Arenas) for allowing us to study their human remains. We also thank Patricia I. Palacio and Asier Goikoetxea for their help with the design of the figures. This research was supported by FONCyT-PICT 0575, PIP 11220120100359 CO from Argentina. Finally, we would like to thank the reviewers for their advice and recommendations.

\section{References Cited}

Albrecht, T.L., S.D. Scutter, and M. Henneberg 2007. Radiographic method to assess the prevalence of Sacral Spina Bifida Occulta. Clinical Anatomy 20:170-174.

Armstrong, S.D. 2012. Spina Bifida at a Pre-Columbian Cuban Site: A Molecular and Paleoepidemological Perspective. $\mathrm{PhD}$ Thesis. Department of Anthropology, University of Manitoba, Winnipeg.

Apazidis, A., P.A. Ricart, C.M. Diefenbach, and J.M. Spivak 2011. The prevalence of transitional vertebrae in the lumbar spine. The Spine Journal 11:858-862.

Avrahami, E., E. Frishman, Z. Fridman, and M. Azor 1994. Spina bifida occulta of s1 is not an innocent finding. Spine 19 (1):12-15.

Barberena, R. 2002. Los Límites del Mar. Sociedad Argentina de Antropología, Buenos Aires.

Barnes, E. 1994. Developmental Defects of the Axial Skeleton in Paleopathology. University of Colorado, Niwot.

Bernal, V., S.I. Pérez, P.N. González, M.L. Sardi, and H.M. Pucciarelli 2010. Spatial patterns and evolutionary processes in Southern South America: A study of dental morphometric variation. American Journal of Physical Anthropology 142 (1):95-104.

Borrero, L.A. 2001. El Poblamiento de Patagonia. Toldos, Milodones y Volcanes. Emecé Editores, Buenos Aires.

Borrero, L. and R. Barberena 2006. Hunter-gatherer home ranges and marine resources: An archaeological case from Southern Patagonia. Current Anthropology 47:855-867.

Borrero, L.A. and F.M. Martin 2018. Archaeological discontinuity in Última Esperanza: A supra-regional overview. Quaternary International 473 (B):290-305.

Bridges, P.S. 1992. Prehistoric arthritis in the Americas. Annual Reviews of Anthropology 21:67-91.

Brooks, S.T. and J.M. Suchey 1990. Skeletal age determination based on the Os pubis: A comparison of the Acsádi-Nemeskéri and Suchey-Brooks Methods. Human Evolution 5:227-238.
Buikstra, J.E. and D.H. Ubelaker 1994. Standards for Data Collection from Human Skeletal Remains. Arkansas Archaeological Survey Research Series No 44, Fayetteville.

Burke, K.L. 2012. Schmörl's nodes in an american military population: Frequency, formation, and etiology. Journal of Forensic Science 57 (3):571-577.

Campo, M. 2003. Paleopatología de la columna vertebral. In Paleopatología: la Enfermedad No Escrita, edited by A. Malgosa and A. Isidro, pp. 403-415. Masson, Barcelona.

Campo, M. 2015. Paleopatología de la Columna Vertebral en la Población Hispanomusulmana de San Nicolás (Murcia, S. XI-XIII). PhD Thesis, Facultad de Medicina, Universidad Complutense de Madrid, Madrid.

Casali, R. 2011. Contacto Interétnico en el Norte de Tierra del Fuego: La Misión Salesiana La Candelaria (Río Grande) y la Salud de la Población Selk'nam (1895-1931). PhD Thesis, Facultad de Historia, Universidad Nacional de Mar del Plata, Mar del Plata, Buenos Aires.

Cocilovo, J. and R.A. Guichón 1986. Propuesta para el estudio de las poblaciones aborígenes del extremo austral de Patagonia. Anales del Instituto de Patagonia (serie Ciencias Humanas) 6:111-123.

Crespo, C.M., M.G. Russo, A. Hajduk, J.L. Lanata, and C.B. Dejean 2017. Variabilidad mitocondrial en muestras precolombinas de la Patagonia argentina. Hacia una visión de su poblamiento desde el ADN antiguo. Revista Argentina de Antropología Biológica 19 (1):1-21.

Crespo, C.M., J.L. Lanata, D.G. Cardozo, S.A. Avena, and C.B. Dejean 2018. Ancient mattern lineages in hunter-gatherer groups of Argentinian Patagonia. Settlement, population continuity and divergence. Journal of Archaeological Science: Reports 18:689-695.

Dar, G., Y. Masharawi, S. Peleg, N. Steinberg, H. May, and B. Medlej 2010. Schmörl's nodes distribution in the human spine and its possible etiology. European Spine Journal 19:670-675. 
D’Angelo del Campo, M.D., J.A. Suby, P. García-Laborde, and R.A. Guichón 2017. Spondylolysis in the past: A case study of hunter-gatherers from Southern Patagonia. International Journal of Paleopathology 19:1-19.

De la Fuente, C., J. Galimany, B.M. Kemp, K. Judd, O. Reyes, and M. Moraga 2015. Ancient marine hunter-gatherers from Patagonia and Tierra del Fuego: diversity and differentiation using uniparentally inherited genetic markers. American Journal of Physical Anthropology 158 (4):719-729.

De la Fuente, C., M. Ávila-Arcos, J. Galimany, M. Carpenter, J.R. Homburger, A. Blanco, P. Contrera, D. Cruz Dávalos, O. Reyes, M. San Román, A. Moreno-Estrada. P.F. Campos, C. Eng, S. Huntsman, E. G. Burchard, A.-S. Malaspinas, C.D. Bustamante, E. Willerslev, E. Llop, R.A. Verdugo, and M. Moraga 2018. Genomic insights into the origin and diversification of late maritime hunter-gatherers from Chilean Patagonia. Proceedings of the National Academy of Sciences 115 (17):e4006-e4012.

Duerson, D.H., R.E. Rodenberg, and J. MacDonald 2016. Spondylolysis in the young athlete. Athletic Training and Sports Health Care 8 (1):5-7.

Eubanks, J.D. and V.K. Cheruvu 2009. Prevalence of sacral spina bifida occulta and its relationship to age, sex, race, and the sacral table angle. Spine 34 (15):1539-1543.

Faccia, K.J. and R.C. Williams 2008. Schmorl's nodes: Clinical significance and implications for the bioarchaeological record. International Journal of Osteoarchaeology 18 (1):28-44.

Ferembach, D. 1963. Frequency of Spina Bifida oculta in Prehistoric Human Skeletons. Nature 190:100-101.

Fidas, A., H.L. MacDonald, R.A. Elton, S.R. Wild, G.D. Chisholm, and R. Scott 1987. Prevalence and patterns of spina bifida occulta in 2707 normal adults. Clinical Radiology 38:537-542.

Fredrickson, B.E., D. Baker, W.J. McHolick, H.A. Yuan, and J.P. Lubicky 1984. The natural history of spondylolysis, and spondylolisthesis in children and adolescents. Journal of Bone and Joint Surgery 66:699-707.

García-Bour, J., A. Pérez-Pérez, S. Álvarez, E. Fernández, A.M. LópezParra, and E. Arroyo Prado 2004. Early population differentiation in extinct aborigines from Tierra del Fuego-Patagonia: ancient mtDNA sequences and Y-chromosome STR characterization. American Journal of Physical Anthropology 123:361-370.

García Laborde, P., J.A. Suby, R.A. Guichón, and R. Casali 2010. El antiguo cementerio de la misión de Rio Grande, Tierra del Fuego. Primeros resultados sobre patologías nutricionalesmetabólicas e infecciosas. Revista Argentina de Antropología Biológica 12 (1):57-69.

García Laborde, P., R.A. Guichón, and N.G. González 2015. Una aproximación tafonómica al antiguo cementerio de la Misión Salesiana de Río Grande, Tierra del Fuego. Arqueología 21 (2):277-290.

García Laborde, P. 2017. Estado Nutricional de la Población Selk'nam: Aproximación Bioarqueológica Al Impacto Generado por la Misionalización. Nuestra Señora de La Candelaria, Tierra del Fuego (XIX-XX). PhD Thesis, Facultad de Ciencias Sociales, Universidad del Centro de la Provincia de Buenos Aires, Olavarría.
González-José, R., C. García Moro, S. Dahinten, and M. Hernández 2002. Origin of Fueguian-Patagonians: an approach to population history and structure using $\mathrm{R}$ matrix and matrix permutation methods. American Journal of Physical Anthropology 14:308-320.

Grogan, J.P., S. Hemminghytt, A.L. Williams, G.F. Carrera, and V.M. Haughton 1982. Spondylolysis studied with computed tomography. Radiology 145:737-742.

Groza, V.M., A. Simalcsik, L. Bejenaru, and R.D. Simalcsik 2016. Spina Bifida Occulta in medieval and postmedieval times in Eastern Romania. Memoirs of the Scientific Sections of the Romania Academy XXXIX:103-115.

Guichón, R.A. 1994. Antropología Física de Tierra del Fuego. Caracterización Biológica de las Poblaciones Prehispánicas. PhD Thesis, Facultad de Filosofía y Letras, Universidad de Buenos Aires, Buenos Aires.

Guichón, R.A., A.S. Muñoz, and L.A. Borrero 2000. Datos para una tafonomía de restos óseos humanos en Bahía San Sebastián, Tierra del Fuego. Relaciones de la Sociedad Argentina de Antropología XXV:297-313.

Guichón, R.A., R. Barberena, and L.A. Borrero 2001. ¿Dónde y cómo aparecen los restos óseos humanos en Patagonia Austral? Anales Instituto Patagonia (serie Ciencias Humanas) 29:103-118.

Guichón, R.A., J.A. Suby, R. Casali, and M.H. Fugassa 2006. Health at the time of native-european contact in Southern Patagonia. First steps, results and prospects. Memorias do Instituto Oswaldo Cruz 101 (Suppl. II):97-105.

Guichón, R.A. and J.A. Suby 2011. Estudio bioarqueológico de los restos humanos recuperados por Anne Chapman en Caleta Falsa, Tierra del Fuego. Magallania 39:163-177.

Haun, D.W. and N.W. Kettner 2005. Spondylolysis and spondylolisthesis: a narrative review of etiology, diagnosis, and conservative management. Journal of Chiropractic Medicine 4 (4):206-217.

Hennenberg, R. and M. Hennenberg 1999. Variation in the closure of the sacral canal in the skeletal sample from Pompeii, Italy, 79 AD. Perspectives in Human Biology 4 (1):177-188.

Hernández, M., C. Lalueza, and C. García-Moro 1997. Fueguian cranial morphology: The adaptation to a cold, harsh environment. American Journal of Physical Anthropology 103:103-117.

Isçan, M.Y., R.S. Loth, and R.K. Wright 1984. Metamorphosis at the sternal rib end: A new method to estimate age at death in white males. American Journal of Physical Anthropology 65:147-156.

Jankauskas, R. 2001. Variations and anomalies of the vertebral column Lithuanian paleoosteological samples. Anthropologie, International Journal of Human Diversity and Evolution XXXIX (1):33-37.

Jiménez-Brobeil, S.A., I.A. Oumaoui, and P. Souich 2010. Some types of vertebral pathologies in the Argar culture (Bronze Age, SE Spain). International Journal of Osteoarchaeology 20 (1):36-46.

Jiménez-Brobeil, S.A., M. Roca-Rodríguez, I.A. Al Oumaoui, and P. Du Souich 2012. Vertebral pathologies and related activity patterns in two mediaeval populations from Spain. Collegium Antropologicum 36 (3):1019-1025. 
Jurmain, R.D. and L. Kilgore 1995. Skeletal evidence of osteoarthritis: A palaeopathological perspective. Annuals of the Rheumatic Dissease 54:443-450.

Kyere, K.A., K.A.D. Than, C.W. Anthony, S.U. Rahman, J.M. Valdivia-Valdivia, F. La Marca, and P. Park 2012. Schmörl's nodes. European Spine Journal 21:2115-2121.

Kumar, A. and S. Tubbs 2011. Spina bifida: A diagnostic dilemma in paleopathology. Clinical Anatomy 24:19-33.

Krenz, J. and J.D.G. Troup 1973. The structure of the pars interarticularis of the lower lumbar vertebrae and its relation to the etiology of spondylolysis. Bone Joint Journal 55 (4):735-741.

Lalueza, C., M. Hernández, and C. García-Moro 1996. Craniometric analysis in groups from Tierra del Fuego/Patagonia and the peopling of the south extreme of the Americas. Human Evolution 11:217-224.

Lalueza, C., A. Pérez-Pérez, E. Prats, L. Cornudella, and D. Turbon 1997. Lack of founding Amerindian mitochondrial DNA lineages in extinct aborigines from Tierra de Fuego Patagonia. Human Molecular Genetics 6:41-46.

L'Heureux, G.L. and R. Barberena 2008. Evidencias bioarqueológicas en patagonia meridional: El sitio Orejas de Burro 1 (Pali Aike, provincia de Santa Cruz). Intersecciones en Antropología 9:11-24.

L'Heureux, G.L. and T. Amorosi 2009. El entierro 2 del sitio Cañadón Leona 5 (Región de Magallanes, Chile). Viejos huesos, nuevos datos. Magallania 37 (2):41-55.

L'Heureux, G.L. and T. Amorosi 2010. El entierro del sitio Cerro Sota (Magallanes, Chile) a más de setenta años de su excavación. Magallania 38 (2):133-149.

Lovejoy, C.O., R.S. Meindl, T.R. Pryzbeck, and R.P. Mensforth 1985. Chronological metamorphosis of the auricular surface of the ilium: A new method for the determination of adult skeletal age at death. American Journal Physical Anthropology 68 (1):15-28.

Masnicová, S. and R. Benus 2003. Developmental anomalies in skeletal remains from the Great Moravia and middle ages cemeteries at Devin (Slovakia). International Journal of Osteoarchaeology 13:266-274.

Martucci, M. 2016. Heterogeneidad Espacial en la Misión Salesiana Nuestra Señora de la Candelaria: Expresión de la Identidad Étnica Selk'nam durante el Proceso de Contacto Interétnico (Río Grande, Tierra del Fuego). PhD Thesis, Facultad de Ciencias Sociales, Universidad Nacional del Centro de la Provincia de Buenos Aires, Olavarría, Buenos Aires.

Merbs, C.F. 1996a. Spondylolysis and spondylolisthesis: a cost of being an erect biped or a clever adaptation? Yearbook of Physical Anthropology 39:201-228.

Merbs, C.F. 1996b. Spondylolysis of the sacrum in Alaskan and Canadian Inuit skeleton. American Journal of Physical Anthropology 101 (3):357-367.

Moreno Estefanell, L., M.D. D’Angelo del Campo, M. Campo Martín, P. García Laborde, O. Cambra-Moo, A. González Martín, and R.A. Guichón 2018. Aproximación a la paleopatología de la columna vertebral en el cementerio de la Misión Salesiana "Nuestra Señora de La Candelaria" (s. XIX-XX, Río Grande,
Argentina). Revista Argentina de Antropología Biológica 20 (2):1-18

Mosothwane, M.N. and M. Steyn 2009. In Sickness or in Health? Assessment of Early Iron Age human skeletons from Toutswe Sites, East Central Botswana. International Journal of Osteoarchaeology 19:66-77.

Mulhern, D.M. and C.A. Wilczak 2012. Frequency of complete Cleft Sacra in a Native American sample. International Journal of Osteoarchaeology 25 (2):226-233.

Ortner, D.J. 2003. Identification of Pathological Conditions in Human Skeletal Remains (2a ed.). Elsevier, San Diego.

Novak, M. and M. Šlaus 2011. Vertebral pathologies in two early modern period (16 ${ }^{\text {th }}-19$ th century) populations from Croatia. American Journal of Physical Anthropology 145 (2):270-281.

Peleg, S., G. Dar, B. Medlej, N. Steinberg, Y. Masharawi, B. Latimer, L. Jellema, N. Peled, B. Arensburg, and I. Hershkovitz 2007. Orientation of the human sacrum: Anthropological perspectives and methodological approaches. American Journal of Physical Anthropology 133:967-977.

Peng, B. 2016. Natural history of lumbar spondylolysis-advances and concerns. International Journal of Orthopaedics 3 (4):591-594.

Pérez, S., V. Bernal, and P. González 2007. Morphological differentiation of aboriginal human populations from Tierra del Fuego (Patagonia): Implications for South American peopling. American Journal of Physical Anthropology 133:1067-1079.

Pérez, S.I. and L.R. Monteiro 2009. Nonrandom factor in modern human morphological diversification: A study of craniofacial variation in Southern South America populations. Human Evolution 63 (4):978-993.

Plomp, K.A. and C.A. Roberts 2012. Vertebral morphology influences the development of Schmörl's nodes in the lower thoracic vertebrae. American Journal of Physical Anthropology 149:572-582.

Rascón, J., O. Cambra-Moo, G. Pimentel, A. González, and M. Campo 2011. Influencia del estado de preservación de los restos óseos en el diagnóstico paleopatológico. Actas del X Congreso Nacional de Paleopatología, edited by A. González, O. Cambra-Moo, J. Rascón, M. Campo, M.M. Robledo and M.E. Labajo, pp. 45-50. Sociedad Española de Paleopatología, Universidad Autónoma de Madrid, Universidad Complutense de Madrid, Madrid.

Real Academia Nacional de Medicina (RANM) 2011. Diccionario de Términos Médicos. Madrid. Panamericana, Madrid.

Rogers, J. and T. Waldron 1995. A Field Guide to Joint Disease in Archaeology. John Wiley \& Sons, Chichester.

Rojas-Sepúlveda, C., Y. Ardagna, and O. Dutour 2008. Paleoepidemiology of vertebral degenerative disease in a preColumbian Muisca Series from Colombia. American Journal of Physical Anthropology 135 (4)aa.416-430.

Saluja, P.G. 1988. The incidence of ossification of the sacroccygeal joint. Journal of Anatomy 156:11-15.

Santiago, F. 2009. La Ocupación Humana del Norte de Tierra del Fuego durante el Holoceno Medio y Tardío. PhD Thesis, Facultad de Ciencias Sociales, Universidad Nacional del Centro de la Provincia de Buenos Aires, Olavarría. 
Santiago, F., M. Salemme, J.A. Suby, and R.A. Guichón 2011. Restos óseos humanos en el norte de Tierra del Fuego. Aspectos contextuales, dietarios y paleopatológicos. Intersecciones en Antropología 12:147-162.

Sarfo, T.A. 2014. A Statistical Investigation of Nonmetric Vertebral Traits with a Skeletal Population Sample from the Dakhleh Oasis, Egypt. Master Thesis, University of Western Ontario, Ontario.

Sarry El-Din, A.M. and R.A. El-Shafy El Banna 2006. Congenital anomalies of the vertebral column: A case study on Ancient and Modern Egypt. International Journal of Osteoarchaeology 16:200-207.

Schmörl, G. and H. Junghanns 1959. The Human Spine in Health and Disease. Grune \& Stratton, New York.

Séguy, I. and L. Buchet 2011. Manuel de Paléodémographie. INED, París.

Seller, M.J. 1994. Risks in spina bifida. Developmental Medicine \& Child Neurolology 36:1021-1025.

Sofaer Derevenski, J.R. 2000. Sex differences in activity-related osseous change in the spine and the gendered division of labor at Ensay and Wharram Percy, UK. American Journal of Physical Anthropology 111:333-354.

Suby, J.A. 2014. Nódulos de Schmorl en restos humanos arqueológicos de Patagonia Austral. Magallania 42 (1):135-147.

Sutow, W.W., A.W. Pryde, and M.A. Kastenbaum 1956. Incidence of Spina Bifida Occulta in relation to age. AMA Am Journal of Diseases of Children 91 (3):211-217.

Todd, T.W. 1921a. Age changes in the pubic bone I: The male white pubis. American Journal of Physical Anthropology 3:285-334.

Todd, T.W. 1921b. Age Changes in the Pubic Bone III: The Pubis of the White Female. American Journal of Physical Anthropology 4:1-70.

Tulsi, R.S. 1972. Vertebral column of the Australian aborigine: selected morphological and metrical feautures. Zeitschrift für Morphologie und Anthropologie 64 (2):117-144.

Üstündağ, H. 2009. Schmörl's nodes in a Post-Medieval skeletal sample from Klostermarienberg, Austria. International Journal of Osteoarchaeology 19 (6):695-710.

Valenzuela, L.O., P. García Laborde, M.D. D’Angelo del Campo, and R.A. Guichón 2019. Transición alimentaria en poblaciones originarias del norte de Tierra del Fuego durante el período misional salesiano: una aproximación isotópica. Revista Argentina de Antropología Biológica 21 (1):1-17.

Van der Merwe, A.E., M.Y. Isçan and E.N. L'Abbè 2006. The pattern of vertebral osteophyte development in a South African Population. International Journal of Osteoarchaeology 16 (5):459-464.

Varela, H., A. Cocilovo, and R.A. Guichón 1993-1994. Evaluaciones de la información somatométrica por Gusinde sobre los aborígenes de Tierra del Fuego. Anales del Instituto de la Patagonia (serie Ciencias Humanas) 22:193-205.

Waldron, T. 1987. The relative survival of the human skeleton: Implications for paleopathology. In Death, Decay and Reconstruction: Approaches to Archaeology and Forensic Science, edited by A. Boddington, A.N. Gardland, and R.C. Janaway, pp. 55-65. Manchester University Press, Manchester.

Waldron, T. 1991. The prevalence of, and the relationship between some spinal diseases in a human skeletal population from London. International Journal of Oteoarchaeology 1:103-110.

Ward, C.V., S.A. Mays, S. Child, and B. Latimer 2010. Lumbar vertebral morphology and isthmic spondylolysis in a British medieval population. American Journal of Physical Anthropology 141:273-280.

Weiss, E. and R. Jurmain 2007. Osteoarthritis revisited: A contemporary review of aetiology. International Journal of Osteoarchaeology 17 (5):437-450.

Williams, F.M.K., N.J. Manek, P.N. Sambrook, T.D. Spector, and A.J. MacGregor 2007. Schmörl's nodes: Common, highly heritable, and related to lumbar disc disease. Arthritis Care Research 57 (5):855-860.

Wynne-Davies, R. and J.H.S. Scott 1979. Inheritance and spondylolisthesis-a radiographic family survey. Journal of Bone Joint Surgery 61:301-305.

Yamada, A., K. Sairyo, I. Shibuya, K. Kato, A. Dezawa, and T. Sakai 2013. Lumbar spondylolysis in juveniles from the same family: a report of three cases and a review of the literature. Case Reports in Orthopedics 1-5.

Zangrando, A. 2009. Historia Evolutiva y Subsistencia de Cazadores-Recolectores Marítimos de Tierra del Fuego. Colección Tesis de Doctorado, Sociedad Argentina de Antropología, Buenos Aires. 